\title{
The impact of the collaborative workplace on the production system capacity: Simulation modelling vs. real-world application approach
}

\author{
Ojstersek, R. ${ }^{a}{ }^{*}$, Javernik, A. ${ }^{a}$, Buchmeister, B. ${ }^{a}$ \\ aUniversity of Maribor, Faculty of Mechanical Engineering, Maribor, Slovenia
}

\begin{abstract}
A B S T R A C T
In recent years, there have been more and more collaborative workplaces in different types of manufacturing systems. Although the introduction of collaborative workplaces can be cost-effective, there is still much uncertainty about how such workplaces affect the capacity of the rest of production system. The article presents the importance of introducing collaborative workplaces in manual assembly operations where the production capacities are already limited. With the simulation modelling method, the evaluation of the introduction impact of collaborative workplaces on manual assembly operations that represent bottlenecks in the production process is presented. The research presents two approaches to workplace performance evaluation, both simulation modelling and a real-world collaborative workplace example, as a basis of a detailed time study. The main findings are comparisons of simulation modelling results and a study of a real-world collaborative workplace, with graphically and numerically presented parameters describing the utilization of production capacities, their efficiency and financial justification. The research confirms the expediency of the collaborative workplaces use and emphasise the importance of further research in the field of their technological and sociological impacts.
\end{abstract}

\author{
ARTICLE INFO \\ Keywords: \\ Simulation modelling; \\ Production system capacity; \\ Industry 5.0; \\ Assembly line; \\ Human-robot collaboration; \\ Collaborative workplace \\ *Corresponding author: \\ robert.ojstersek@um.si \\ (Ojstersek, R.) \\ Article history: \\ Received 7 September 2021 \\ Revised 11 December 2021 \\ Accepted 13 December 2021

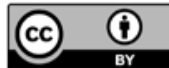 \\ Content from this work may be used under the terms of \\ the Creative Commons Attribution 4.0 International \\ Licence (CC BY 4.0). Any further distribution of this work \\ must maintain attribution to the author(s) and the title of \\ the work, journal citation and DOI.
}

\section{References}

[1] Moniz, A.B., Krings, B.-J. (2016). Robots working with humans or humans working with robots? Searching for social dimensions in new human-robot interaction in industry, Societies, Vol. 6, No. 3, Article No. 23, doi: $10.3390 /$ soc6030023.

[2] Michalos, G., Makris, S., Tsarouchi, P., Guasch, T., Kontovrakis, D., Chryssolouris, G. (2015). Design considerations for safe human-robot collaborative workplaces, Procedia CIRP, Vol. 37, 248-253, doi: 10.1016/j.procir.2015. 08.014 .

[3] Nahavandi, S. (2019). Industry 5.0-A human-centric solution, Sustainability, Vol. 11, No. 16, Article No. 4371, $\underline{\text { doi: }}$ $10.3390 /$ su11164371.

[4] Özdemir, V., Hekim, N. (2018). Birth of Industry 5.0: Making sense of big data with artificial intelligence,"The Internet of Things" and next-generation technology policy, OMICS: A Journal of Integrative Biology, Vol. 22, No. 1, 65-76, doi: 10.1089/omi.2017.0194.

[5] Gualtieri, L., Rauch, E., Vidoni, R. (2021). Emerging research fields in safety and ergonomics in industrial collaborative robotics: A systematic literature review, Robotics and Computer-Integrated Manufacturing, Vol. 67, Article No. 101998, doi: 10.1016/j.rcim.2020.101998.

[6] Leber, M., Bastič, M., Moody, L., Schmidt Krajnc, M. (2018). A study of the impact of ergonomically designed workplaces on employee productivity, Advances in Production Engineering \& Management, Vol. 13, No. 1, 107-117, doi: 10.14743/apem2018.1.277. 
[7] Mateus, J.E.C., Claeys, D., Limère, V., Cottyn, J., Aghezzaf, E.-H. (2019). Ergonomic and performance factors for Human-robot collaborative workplace design and evaluation, IFAC-PapersOnLine, Vol. 52, No. 13, 2550-2555, doi: 10.1016/j.ifacol.2019.11.590.

[8] Lasota, A.M. (2020). A new approach to ergonomic physical risk evaluation in multi-purpose workplaces, Tehnički Vjesnik - Technical Gazette, Vol. 27, No. 2, 467-474, doi: 10.17559/TV-20180312131319.

[9] Ojstersek, R., Acko, B., Buchmeister, B. (2020). Simulation study of a flexible manufacturing system regarding sustainability, International Journal of Simulation Modelling, Vol. 19, No. 1, 65-76, doi: 10.2507/ijsimm19-1-502.

[10] Ojstersek, R., Buchmeister, B. (2020). Simulation modeling approach for collaborative workplaces' assessment in sustainable manufacturing, Sustainability, Vol. 12, No. 10, Article No. 4103, 18 pages, doi: 10.3390/su12104103.

[11] Nikolakis, N., Maratos, V., Makris, S. (2019). A cyber physical system (CPS) approach for safe human-robot collaboration in a shared workplace, Robotics and Computer-Integrated Manufacturing, Vol. 56, 233-243, doi: 10.1016/j.rcim.2018.10.003.

[12] Koppenborg, M., Nickel, P., Naber, B., Lungfiel, A., Huelke, M. (2017). Effects of movement speed and predictability in human-robot collaboration, Human Factors and Ergonomics in Manufacturing \& Service Industries, Vol. 27, No. 4, 197-209, doi: 10.1002/hfm.20703.

[13] Wang, Y., Cen, H.J., Yang, O. (2018). Optimal configuration for workshop manufacturing system under dual resource constraints, International Journal of Simulation Modelling, Vol. 17, No. 1, 180-189, doi: 10.2507/ijsimm17 (1) $\cos$.

[14] Gualtieri, L., Rauch, E., Vidoni, R. (2021). Methodology for the definition of the optimal assembly cycle and calculation of the optimized assembly cycle time in human-robot collaborative assembly, The International Journal of Advanced Manufacturing Technology, Vol. 113, No. 7, 2369-2384, doi: 10.1007/s00170-021-06653-y.

[15] Ojstersek, R., Tang, M., Buchmeister, B. (2020). Due date optimization in multi-objective scheduling of flexible job shop production, Advances in Production Engineering \& Management, Vol. 15, No. 4, 481-492, doi: 10.14743/apem 2020.4.380.

[16] Trstenjak, M., Ćosić, P., Antolić, D. (2019). Workpiece classification criteria in automated process planning, Tehnički Vjesnik - Technical Gazette, Vol. 26, No. 1, 256-262, doi: 10.17559/TV-20180215105405.

[17] Zheng, Z.L., Bao, X. (2019). The investment strategy and capacity portfolio optimization in the supply chain with spillover effect based on artificial fish swarm algorithm, Advances in Production Engineering \& Management, Vol. 14, No. 2, 239-250, doi: 10.14743/apem2019.2.325.

[18] Katić, I., Berber, N., Slavić, A., Ivanišević, A. (2020). The relations between investment in employees' development and organizational productivity and service quality, Tehnički Vjesnik - Technical Gazette, Vol. 27, No. 4, 1077 1083, doi: $10.17559 / T V-20181121101314$.

[19] Kunpeng, Y., Jiafu, S., Hui, H. (2017). Simulation of collaborative product development knowledge diffusion using a new cellular automata approach, Advances in Production Engineering \& Management, Vol. 12, No. 3, 265-273, doi: 10.14743/apem2017.3.257.

[20] Fechter, M., Seeber, C., Chen, S. (2018). Integrated process planning and resource allocation for collaborative robot workplace design, Procedia CIRP, Vol. 72, 39-44, doi: 10.1016/i.procir.2018.03.179.

[21] Rega, A., Vitolo, F., Di Marino, C., Patalano, S. (2021). A knowledge-based approach to the layout optimization of human-robot collaborative workplace, International Journal on Interactive Design and Manufacturing, Vol. 15, No. 1, 133-135, doi: 10.1007/s12008-020-00742-0.

[22] Mateus, J.C., Claeys, D., Limère, V., Cottyn, J., Aghezzaf, E.-H. (2019). A structured methodology for the design of a human-robot collaborative assembly workplace, The International Journal of Advanced Manufacturing Technology, Vol. 102, No. 5, 2663-2681, doi: 10.1007/s00170-019-03356-3. 


\section{APEM}

\title{
Vpliv sodelovalnega delovnega mesta na zmogljivost proizvodnega sistema: Pristop primerjave simulacijskega modeliranja $\mathrm{z}$ realno uporabo
}

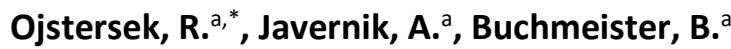 \\ aUniversity of Maribor, Faculty of Mechanical Engineering, Maribor, Slovenia
}

\begin{abstract}
POVZETEK
$\mathrm{V}$ zadnjih letih je $\mathrm{v}$ različnih vrstah proizvodnih sistemov navzočih vse več sodelovalnih delovnih mest. Čeprav je lahko uvedba sodelovalnih delovnih mest stroškovno učinkovita, je še vedno veliko negotovosti o tem, kako takšna delovna mesta vplivajo na zmogljivost preostalega proizvodnega sistema. Članek predstavlja pomen uvajanja sodelovalnih delovnih mest pri ročnih montažnih operacijah, kjer so proizvodne zmogljivosti omejene. Z metodo simulacijskega modeliranja je narejena ocena vpliva sodelovalnih delovnih mest na ročne montažne operacije, ki predstavljajo ozka grla v proizvodnem procesu. Raziskava, kot osnovo za podrobno časovno študijo, predstavlja dva pristopa k vrednotenju uspešnosti na delovnem mestu, simulacijski model in primer sodelovalnega delovnega mesta v resničnem svetu. Glavne ugotovitve raziskave so predstavljene $\mathrm{v}$ obliki primerjave rezultatov simulacijskega modeliranja in študije realnega sodelovalnega delovnega mesta z grafično in numerično prikazanimi parametri, ki opisujejo izkoriščenost proizvodnih zmogljivosti, njihovo učinkovitost in finančno upravičenost. Raziskave potrjujejo smotrnost uporabe sodelovalnih delovnih mest in poudarjajo pomen nadaljnjih raziskav na področju njihovih tehnoloških in socioloških vplivov.
\end{abstract}

\section{PODATKI O ČLANKU}

Ključne besede:

Simulacijsko modeliranje;

Zmogljivost proizvodnega sistema; Industrija 5.0;

Montažna linija;

Sodelovanje človek-robot;

Sodelovalno delovno mesto

*Kontaktna oseba: robert.ojstersek@um.si (Ojstersek, R.)

Zgodovina članka:

Prejet 7. septembra 2021

Popravljen 11. decembra 2021

Sprejet 13. decembra 2021

\section{(i)}

Content from this work may be used under the terms of the Creative Commons Attribution 4.0 International Licence (CC BY 4.0). Any further distribution of this work must maintain attribution to the author(s) and the title of the work, journal citation and DOI. 